\title{
EUTROPHICATION IN SPANISH FRESHWATER ECOSYSTEMS
}

\author{
M. Alvarez Cobelas, A. Rubio Olmo and P. Muñoz Ruiz \\ Centro de Investigaciones del Agua (CSIC), La Poveda. Arganda del Rey, E-28500 Madrid. Spain.
}

Keywords: Eutrophication, Phosphorus, Ecosystem typology, Major Watersheds, Spain.

\begin{abstract}
An account on the eutrophication of Spanish freshwaters is given here, based upon both published and unpublished data. Phosphorus was chosen as eutrophication index. Major watersheds and ecoaystem types were ranked by using yearly P-averages. On the whole, 713 sites are known for P-data. Júcar, Tajo and Eastern Pyrenees are the most heavily eutrophicated watersheds, whereas Duero, Segura and Southern watersheds show the least P contents. However, within and between variabilities are very high. On the whole, streams are more eutrophic than stagnant waters but again variability in $\mathrm{P}$ contents within and between ecosystem types is high. Lakes show very strikingly trophic degrees, depending upon lake tipology and their environment. On an average basis, 80\% Spanish lakes, 70\% reservoirs and 60\% river sites are eutrophic. In water courses, hypertrophy is increasing downstream.
\end{abstract}

\section{INTRODUCTION}

In Spain, water quality standards have been largely neglected in the past despite the fact that water itself is an endangered, very scarce natural resource in our country. Average rainfall is very low in most areas, as compared with other temperate countries (OLIVER \& FAIRBRIDGE, 1987), and experiences a remarkable seasonality. This results both in high water level (in stagnant waterbodies) and water discharge (in streams) fluctuations throughout the year. These facts, i.e. neglecting water quality and fluctuating rainfall, are the main features operating on Spanish water resources and rendering them highly polluted in most cases.

Unfortunately, there have been but a few attempts to fully survey water quality of Spanish freshwater ecosystems up to date (i.e., MINGO, 1983). Of course, several independent reports have been produced (MARGALEF et al., 1977; ORTIZ CASAS \& PENA, 1984; PRAT et al., 1985) but they are either local or not updated, which is a problem because of the high variability of water quality in Spanish waterbodies (RIERA et al., 1991).

Therefore, it is our aim here to provide a brief, up-dated account of water quality of Spanish freshwater ecosystems. Eutrophication is perhaps the best known of all processes threatening water quality. Nowadays, the key

Limnetica, 8: 263-266 (1992)

O Asociación Española de Limnología, Madrid. Spain role of phosphorus in eutrophication events is widely recognized (OECD, 1982), and, accordingly, we shall use phosphorus concentrations as an index of eutrophication in Spanish freshwater ecosystems, and hence as a water quality index.

\section{MATERIALS AND METHODS}

This study has been carried out with already existing data sets (published or not). All members of the AEL (Spanish Limnological Association) were requested to contribute data on phosphorus contents in freshwater ecosystems, but only those data sets covering a whole year were used. Also published literature was searched on the topic. When two distinct data sets on any given site were found, the most recent one was chosen. Phosphorus data have been yearly averaged for any site throughout the study to provide a proper basis for comparisons since the sharp seasonality in Spanish freshwaters prevents meaningful comparisons if only single samples were used.

We classified the study sites according to ecosystem type and their affiliation to the major watershed. The former were included: irrigation channels, lakes, reservoirs, rivers, salt marshes, salt works, springs and temporary streams. The latter included: Northern watershed, Duero, Tajo, Guadiana, 
Guadalquivir, Southern watershed, Segura, Júcar, Ebro and Eastern Pirineo (fig. 1).

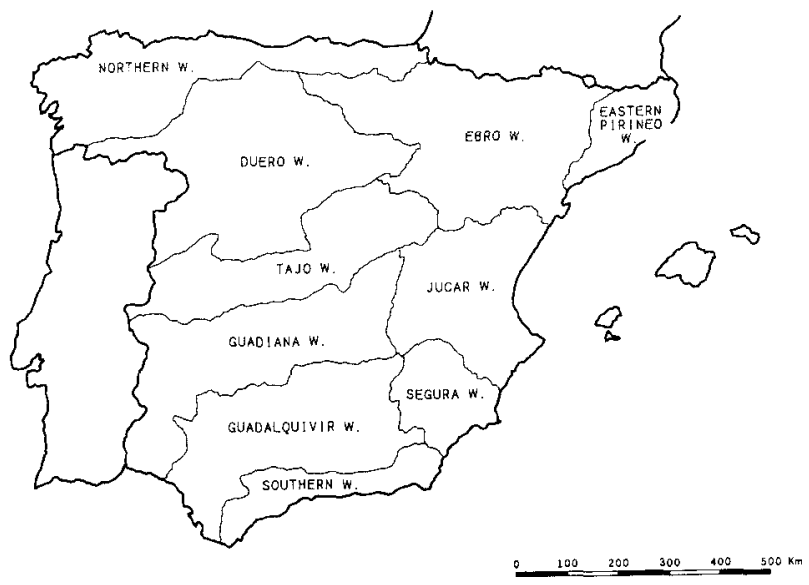

Figure 1. Spanish major watersheds

Although total phosphorus is the most remarkable feature of the P- pool in freshwaters, its concentration is not routinely measured in Spanish ecosystems. This is the reason why we have to rely on SRP (Soluble Reactive Phosphorus), which is measured more frequently. Then, linear functions between SRP and total P have been calculated for any ecosystem type or major watershed concerned in order to make use of a total P-based trophic classification (OECD, 1982).

Trophic degrees were ascertained for stagnant waters after OECD criteria (1982: table 7.2). Unfortunately, no criteria on trophic degrees are available for streams. We, therefore, used a biological criterion. In most Spanish streams the phanerogam Potamogeton pectinatus usually appears under eutrophication, corresponding to total-P contents in excess of $0.15 \mathrm{mg} \mathrm{P} / \mathrm{l}$. So such a value has been chosen as a boundary between meso- and eutrophic conditions ( $\mathrm{N}$. PRAT, pers. comm.). The remain'der trophic degrees have been selected on proportionality grounds (mesotrophic boundary: $0.03 \mathrm{mg} \mathrm{P} / \mathrm{l}$; hypertrophic boundary $>0.30 \mathrm{mg}$ $\mathrm{P} / \mathrm{l}$ ). Admittedly, trophic degree criteria for stagnant waterbodies and streams differ, the latter being much higher (four-fold aprox.), as a consequence of the use of Potamogeton pectinatus as water quality indicator.

\section{RESULTS}

The number of sites for which yearly average, $P$ contents have been compiled is 713 (ALVAREZ COBELAS et al.,
1991). Ebro and Northern watersheds are the best known areas whereas rivers and reservoirs are the best known ecosystem types.

Júcar, Tajo and Eastern Pirineo are the most heavily eutrophied watersheds, Southern watershed, Duero and Segura being the least ones. However, both between and within variability is high (CVs ranging $100-200 \%$, fig. 2). The contribution of natural eutrophication to these values is

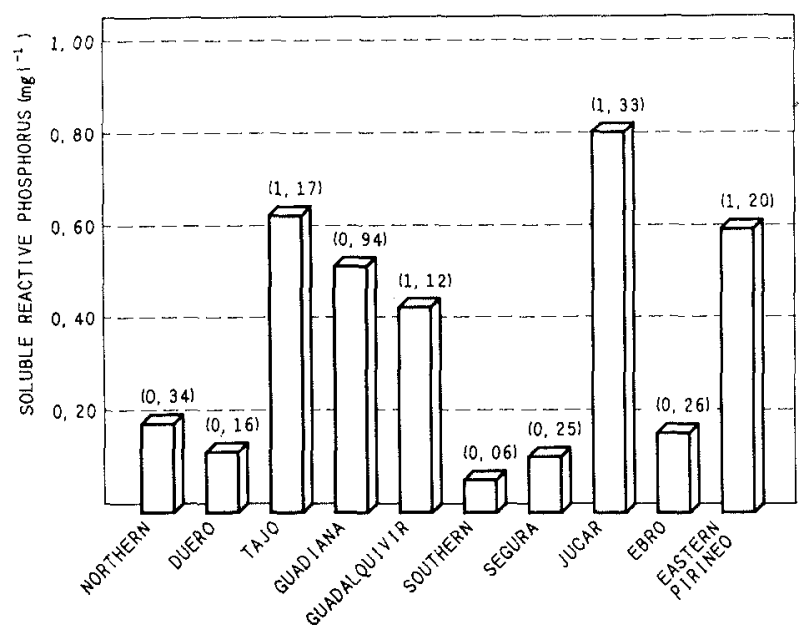

Figure 2. Average SRP values for major Spanish watersheds. Standard deviations in brackets.

negligible since Tajo and Duero watersheds mostly lie on acidic areas whereas Pirineo and Segura lie on calcareous areas. So an explanation to the observed patterns must be searched on man-made eutrophication. For example, the Tajo watershed is heavily eutrophied by Madrid city ( 5 million people) wastewaters, whereas the Júcar watershed is very important in agricultura1 practices, and the Eastern Pyrenees is one of the most industrialized areas all over Spain. On the contrary, the Southern watershed, despite being highly populated, discharges most sewage waters to the Mediterranean Sea instead of to freshwater ecosystems. The Duero basin has both a relatively high water discharge and low human population. For the Segura basin pollution resulting from agricultural practices is important only in its lower reaches.

Streams had the highest $\mathrm{P}$ content (fig. 3), stagnant waters having, on the average, phosphorus concentrations 4-fold smaller than those in streams. Anyway, variability is the rule (50-700\% CV within ecosystem types). Very interestingly, lakes appear to have higher $\mathrm{P}$ contents than reservoirs, albeit with lower variabilities. This is explained by the diversity of lake types in Spain (alpine, karstic, saline, littoral, pits, 


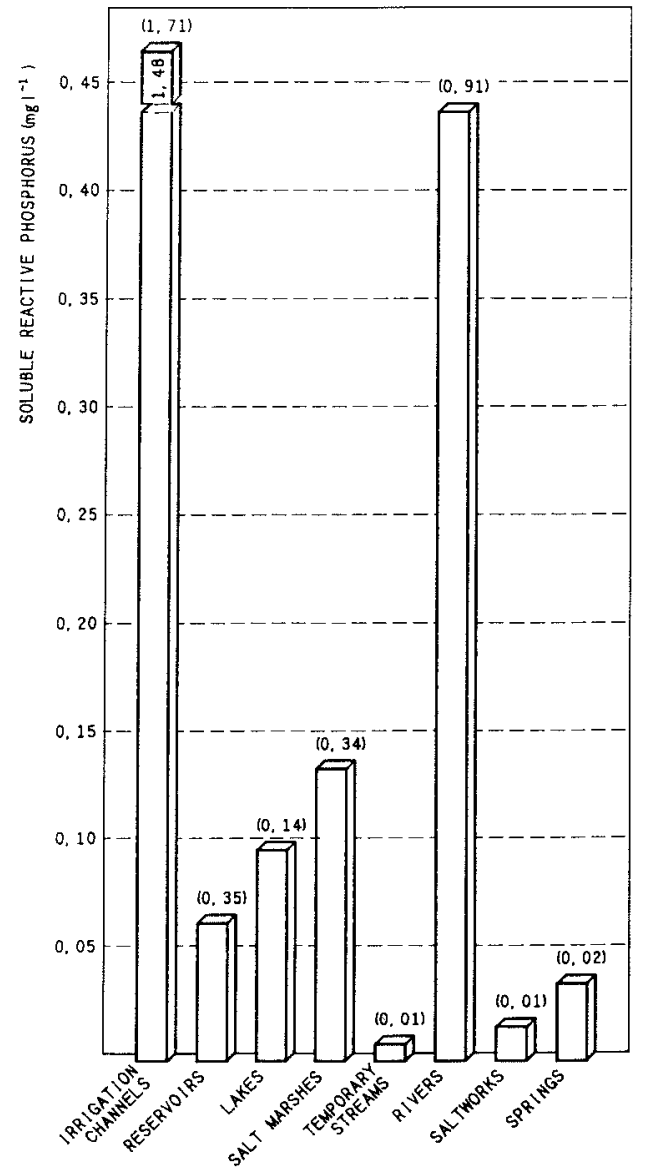

Figure 3. Average SRP in Spanish freshwater ecosystems. Standard deviations in brackets.
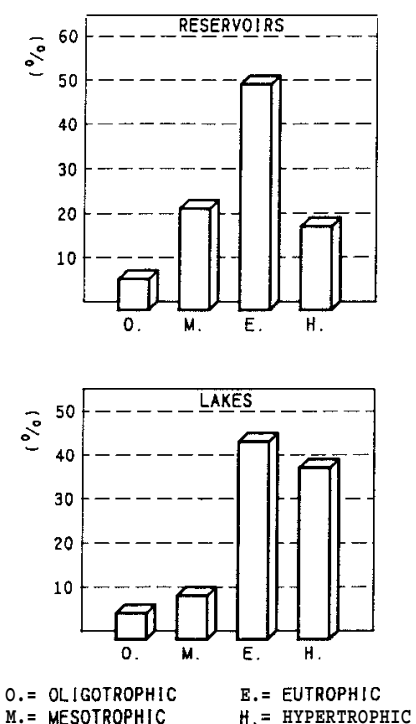

Figure 4. Trophic degree (\%) of Spanish reservoirs and lakes following OECD (1982) total Phosphorus criterion.
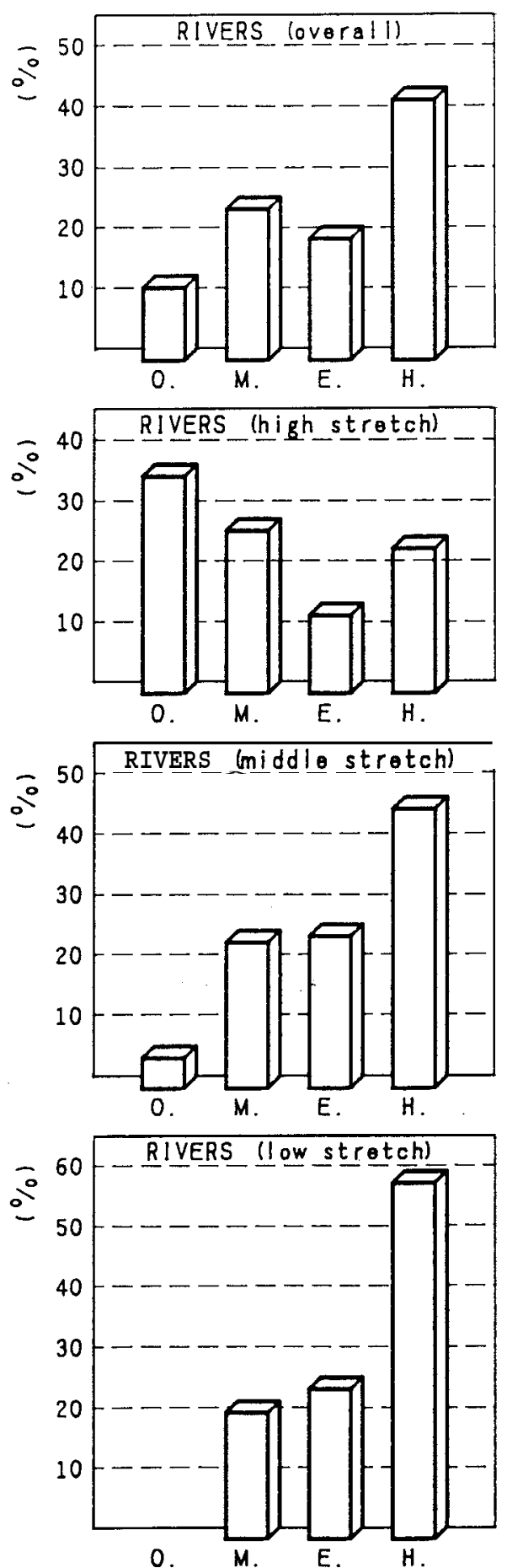

$$
\begin{array}{ll}
\text { O.= OL IGOTROPHIC } & \text { E. }=\text { EUTROPH IC } \\
\text { M.= MESOTROPHIC } & \text { H. }=\text { HYPERTROPHIC }
\end{array}
$$

Figure 5. Trophic degree $(\%)$ of Spanish rivers. The criterion used is outlined in the Materials and Methods' section. Also trophic degree in different river stretches is shown. 
etc.). So karstic and alpine lakes show $0.030-0.034 \mathrm{mg} \mathrm{P} / \mathrm{I}$ (measured as SRP) whereas the remainder lakes are much more eutrophic $(0.106-0.144 \mathrm{mg} / \mathrm{P})$.

As shown by OECD criteria using total P, $80 \%$ Spanish lakes are eutrophic, with hypertrophy accounting for half such a figure. Around $70 \%$ reservoirs are eutrophic but hypertrophy is still much lower ( $20 \%$, fig. 4$)$. Concerning rivers, $60 \%$ out of the total sites are eutrophic (fig. 5), the least eutrophic stretches being at the high course (fig. 5), but in middle and low stretches most sites are eutrophic (68\% and $82 \%$, respectively), and hypertrophy increases dramatically downstream.

\section{CONCLUSIONS}

As a concluding remark, it is obvious that surface water quality in Spain is far from good standards. But we hope that some remedial actions could be implemented in the near future.

\section{ACKNOWLEDGEMENTS}

This study could have not been undertaken without the financial support by Henkel Ibérica. Mr. Antonio Rosas (Environmental Chairman of Henkel Staff) was extremely helpful in coordination and suggestions. Prof Narcis Prat has provided a lot of useful comments and ideas before the study and on earlier drafts of manuscript. AEL (Spanish Limnological Association) promoted this study and many of its Members supplied unpublished data. They are too numerous to mention them all but we are very grateful to them. Our deep gratitude is also due to an anonymous referee whose suggestions have greatly improved this study. Finally, Fernando Delgado has kindly drawn the figures and Julián Michel checked the English language of the manuscript.

\section{REFERENCES}

ALVAREZ COBELAS, M.; P. MUÑOZ \& A. RUBIO. 1991. La Eutrofización de las Aguas continentales españolas. HENKEL IBERICA, S.A. Barcelona. 338 pp.

MARGALEF. R.; D. PLANAS; J. ARMENGOL; A. VIDAL; N. PRAT; A. GUISET; J. TOJA \& M. ESTRADA. 1977. Limnología de los Embalses españoles. MOPU. Madrid. 422 pp. + appendixes.

MINGO, J. 1983. La Vigilancia de la Contaminación fluvial. MOPU. Madrid. 75 pp. + appendixes.

O.E.C.D. 1982. Eutrophication of Waters. Monitoring, Assessment and Control. O.E.C.D. Paris. 154 pp.

OLIVER, J.E. \& R.W. FAIRBRIDGE (eds). 1987. The Encyclopedia of Climatology. Encyclopedia of Earth Sciences, XI. Van Nostrand Reinhold Co. New York. xvi + $986 \mathrm{pp}$.

ORTIZ-CASAS, J.L. \& R. PENA. 1984. Applicability of the OECD eutrophication models to Spanish reservoirs. Verh. Internat. Verein. Limnol. 22: 1521-1535.

PRAT, N.; G. GONZALEZ, X. MILLET \& M.A. PUIG. 1985. El Foix. enti-e l'eixutesa i la contaminació. Servei Medi Ambient. Dipt. Barcelona. Est. Mongr., 11.92 pp.

RIERA, J.L., E. MARTI \& J.A. MORGUI. 1991. Changes in the trophic state of the Spanish reservoirs during the last sixteen years. Verh. Internat. Verein. Limnol. 24: 1367-1370. 